\title{
New record of three freshwater fish species from a western drainage of Lake Urmia for the Turkish fauna
}

\section{Urmia Gölü'nün batı drenajından Türkiye faunası için üç yeni tatlısu balık türü kaydı}

\section{Cüneyt Kaya}

Recep Tayyip Erdogan University, Faculty of Fisheries and Aquatic Sciences, 53100 Rize, Turkey

https://orcid.org/0000-0002-4531-798X

cnytkaya@yahoo.com

Received date: 11.03 .2020

Accepted date: 13.05 .2020

How to cite this paper:

Kaya, C. (2020). New record of three freshwater fish species from a western drainage of Lake Urmia for the Turkish fauna. Ege Journal of Fisheries and Aquatic Sciences, 37(4), 325-328. DOI: 10.12714/egejfas.37.4.01

Abstract: In the scope of this study, three freshwater fish species were newly recorded for Turkey from a western drainage of Lake Urmia: Alburnoides petrubanarescui, Alburnus atropatenae and Oxynoemacheilus elsae. All of them were found in headwaters of Nazli-chay River in the basin of the hypersaline Lake Urmia. The Lake is fed by many small springs and thirteen permanent rivers. However, it is still seriously threatened and drying up rapidly. In the previous studies, the existence of a stream in the western part of the Urmia Lake within border of Turkey was not mentioned.

Keywords: Anatolia, Nemacheilidae, Leuciscidae, first record

Öz: Bu çalışma kapsamında, Urmia Gölü'nün batı drenajından Türkiye için üç yeni tatı su balığı türü bildirilmişir: Alburnoides petrubanarescui, Alburnus atropatenae ve Oxynoemacheilus elsae. Bu türlerin hepsi yüksek tuzluluğa sahip Urmia Gölü havzasındaki Nazlı Çay'ın membalarında tespit edilmiştir. Bu göl, birçok küçük su kaynağı ve 13 devamlı nehir ile beslenmektedir. Ama yine de ciddi tehdit alıındadır ve hızla kurumaktadır. Daha önceki çalışmalarda, Urmiye Gölü havzasının batı kesiminde Türkiye sınırları içerisinde ki akarsuların mevcudiyetinden bahsedilmemiştir.

Anahtar kelimeler: Anadolu, Nemacheilidae, Leuciscidae, yeni kayit

\section{INTRODUCTION}

Lake Urmia (also known as Orumiyeh) is located in northwest Iran. The lake is one of the largest permanent hypersaline lakes in the world and has an importance on biodiversity in the area (Kelts and Shahrabi, 1986) but the lake level has fallen dramatically during the last decades, and the salinity of the lake has strongly increased due to human activities and poor management. Meanwhile, the lake is almost dried out (Jörg Freyhof, pers. comm, 2018).

The ichthyofauna of Lake Urmia basin was reviewed by Ghasemi et al. (2015) and they listed 29 fish species, five of which are endemic to the lake basin. These are; Acanthobrama urmianus (Günther, 1899), Alburnoides petrubanarescui (Bogutskaya and Coad, 2009), Alburnus atropatenae (Berg, 1925), Petroleuciscus ulanus (Günther, 1899) and Romanogobio persus (Günther, 1899). Recently, an additional endemic species (Oxynoemacheilus elsae) has been described from the Zarineh-Simineh, Sofi and Mahabad rivers draining to Lake Urmia (Eagderi et al., 2018). On the other hand, eleven exotic species inhabit the Lake basin: Carassius auratus (Linnaeus, 1758), Carassius gibelio (Bloch, 1782), Ctenopharyngodon idella (Valenciennes, 1844), Cyprinus carpio Linnaeus, 1758, Hemiculter leucisculus (Basilewsky, 1855), Hypophthalmichthys molitrix
(Valenciennes, 1844), Pseudorasbora parva (Temminck \& Schlegel, 1846), Oncorhynchus mykiss (Walbaum, 1792), Gambusia holbrooki (Girard, 1859), Sander lucioperca (Linnaeus, 1758), Rhinogobius similis (Gill, 1859). There are thirteen permanent rivers and many small springs in Lake Urmia basin, all of them within the borders of Iran (Eimanifar and Mohebbi, 2007; Stevens et al., 2012) except one small stream, which has its upper parts in Turkey. This drainage of Lake Urmia (headwater of Nazli-chay River) originates from the Mor Mountain (about $25 \mathrm{~km}$ inside from the Esendere customs) which is located near Kısıklı village, Turkey. The second stream source from eastern Yüksekova drains to Nazli-chay River in Iran. The presence of these streams in Turkish boundaries had never been mentioned by the researchers who conducted taxonomic studies in the upper Great Zap River which is geographically very close to the area (Kaya et al., 2016; Kelle, 1978; Kuru, 1975). Ghasemi et al. (2015) recognized four species in Nazli-chay River: Alburnus atropatenae, Capoeta capoeta, Barbus cyri and Oxynoemacheilus brandtii. Here, I have attempted to determine the fish species inhabit this stream, because of the possibility to occurrences of potential native fish records for Turkish freshwaters. 


\section{MATERIALS AND METHODS}

This survey was conducted on streams Esendere (headwater of Nazli-chay River) and Onbaşılar (a drainage of Nazli-chay River). Esendere Stream is about $25 \mathrm{~km}$ in Turkey. After leave the Turkish boundaries, it flows about $60 \mathrm{~km}$ to the east towards the Lake Urmia. Onbaşılar Stream source from $20 \mathrm{~km}$ east of Yüksekova and it is about $15 \mathrm{~km}$ Turkey.

Fish samples were caught with pulsed DC electro-fishing equipment at five sampling sites in September 2019 in Esendere and Onbaşılar streams, southeast of Anatolia
(Table 1; Figure 1). After anaesthesia using MS-222, the collected materials were fixed in $5 \%$ formaldehyde solution and transferred to the laboratory for morphological investigation. Bogutskaya and Coad (2009), Eagderi et al. (2018) and Khaefi et al. (2017) were followed to identify the fishes. The map (Figure 1) was created using the Qgis v. 2.6.1-Brighton software.

Abbreviations: SL: standard length; FFR: Zoology Museum of the Faculty of Fisheries, Recep Tayyip Erdogan University, Rize, Turkey.

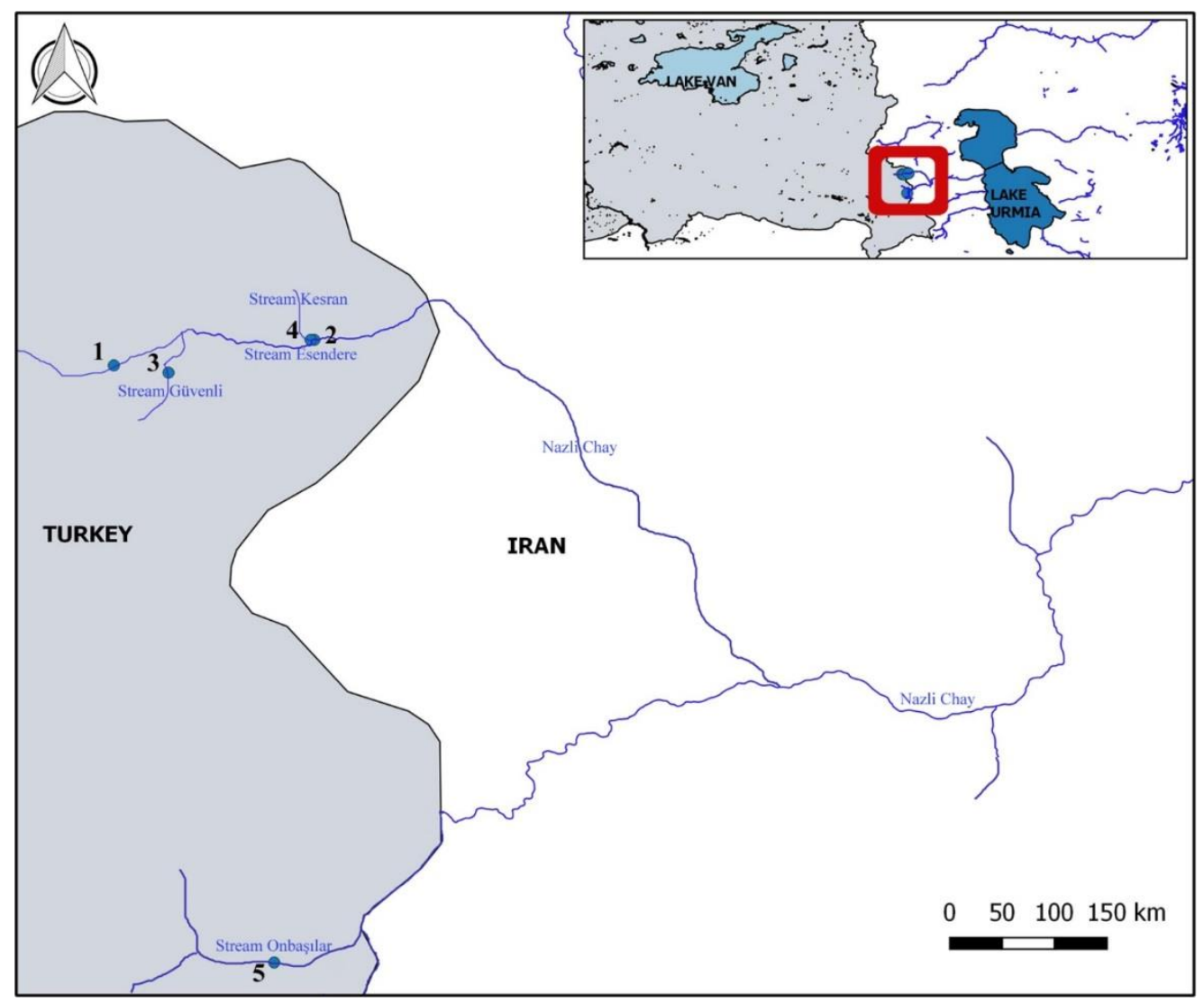

Figure 1. Sampling sites in the survey area

Table 1. Sampling sites in the area and the species obtained during the survey

\begin{tabular}{llll}
\hline & Stream & Coordinates & Species \\
\hline 1 & Esendere (upper part) & $37.707891 \mathrm{~N}$ 44.549040E & Barbus cyri, Alburnoides petrubanarescui \\
2 & Esendere (lower part) & $37.714213 \mathrm{~N}$ 44.604656E & Barbus cyri, Alburnoides petrubanarescui \\
3 & Güvenli & $37.705966 \mathrm{~N} 44.564413 \mathrm{E}$ & Barbus cyri, Alburnoides petrubanarescui \\
4 & Kesran & $37.714035 \mathrm{~N} 44.603367 \mathrm{E}$ & Oxynoemacheilus elsae \\
5 & Onbaşılar & $37.544105 \mathrm{~N} 44.593580 \mathrm{E}$ & Alburnus atropatenae, Barbus cyri, Alburnoides petrubanarescui \\
\hline
\end{tabular}




\section{RESULTS}

In the present study, four species were found in the Esendere and Onbaşılar streams. Three of them new record for fish fauna of Turkey (Alburnoides petrubanarescui, Alburnus atropatenae and Oxynoemacheilus elsae). Fourth species is Barbus cyri which occurs also in Turkish Kura-Aras drainages (Kaya et al. 2020).

Alburnoides petrubanarescui Bogutskaya \& Coad, 2009 (Figure 2)

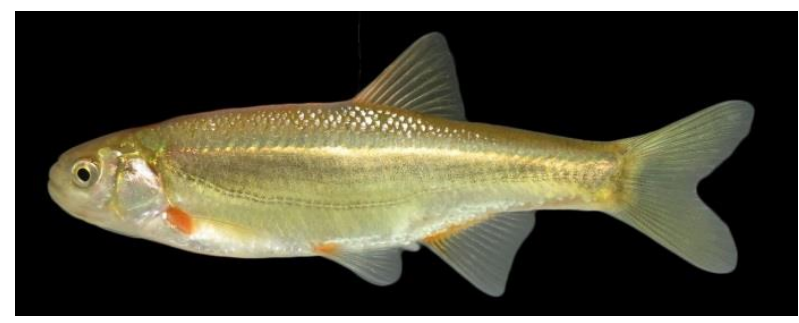

Figure 2. Alburnoides petrubanarescui, FFR 7016, $73 \mathrm{~mm} \mathrm{SL}$, Esendere Stream

Common name. Urmia spirlin

Type locality. Qasemlou Chay, Urmia Lake basin

Distribution. The species is known from only in Lake Urmia basin. Here, the species was found in Esendere and Onbaşıllar streams.

\section{Alburnus atropatenae Berg, 1925 (Figure 3)}

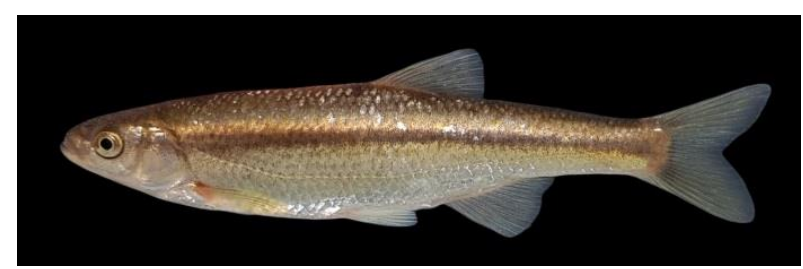

Figure 3. Alburnus atropatenae, FFR 8814, 125 mm SL, Onbaşılar Stream

\section{Common name. Urmia bleak}

Type locality. Qasemlou Chay, Urmia Lake basin

Distribution. The species is known from only in Lake Urmia basin. Here, the species was found in Onbaşılar Stream.

\section{(Figure 4)}

Oxynoemacheilus elsae Eagderi, Jalili \& Çiçek, 2018

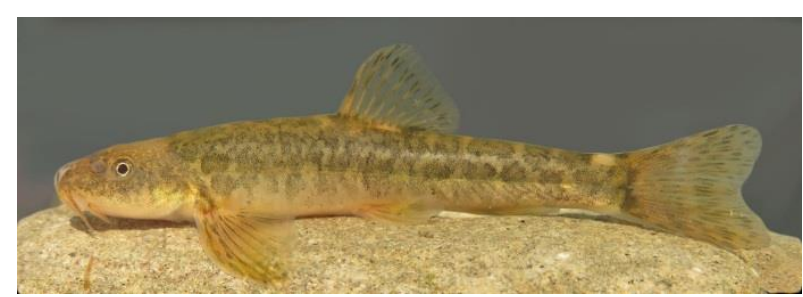

Figure 4. Oxynoemacheilus elsae, FFR 15536, 53 mm SL, Kesran Stream

Common names. Urmia loach
Type locality. Zarineh River, near Shahin-Dej city, Urmia Lake basin

Distribution. Oxynoemacheilus elsae described from Zarineh-Simineh, Sofi and Mahabad rivers drainages, Lake Urmia basin, Iran. Here, the species was found in Kesran Stream where is the draining to Esendere Stream (Figures 1 and 5).

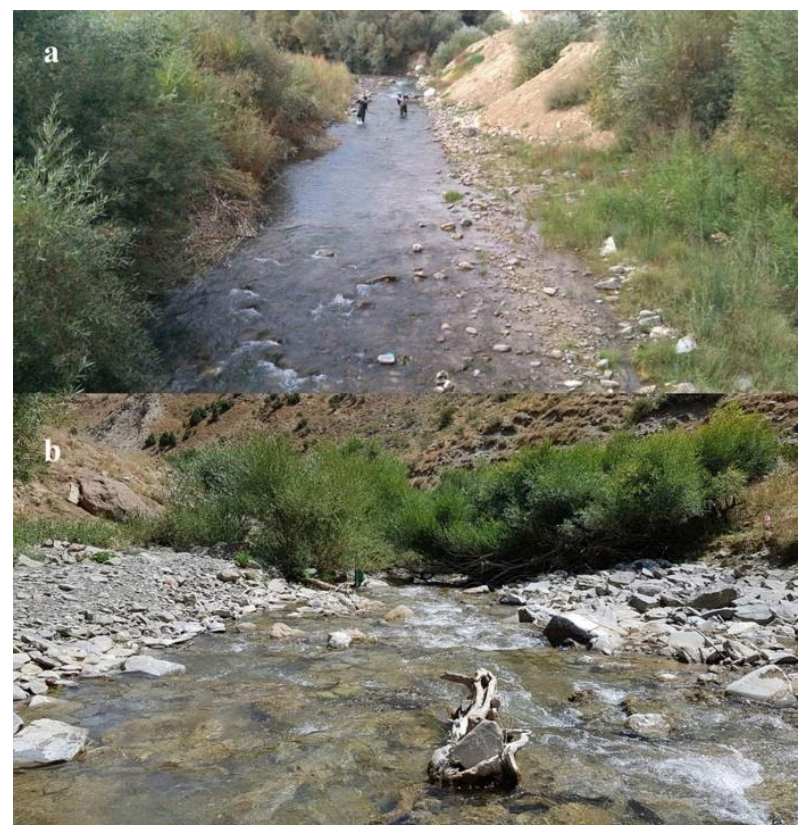

Figure 5. View of sampling sites; a, Esendere Stream; b, Onbaşılar Stream

\section{DISCUSSION}

Before the visit the Esendere and Onbaşılar streams I had expected to found more fish species in the area. Despite the intensive sampling of the appropriate habitats of the Oxynoemacheilus elsae, only one individual of the species was found. In Esendere Stream, which has a generally shallow and fast flowing structure, no Alburnus atropatenae was found. In Onbaşllar Stream, six adult samples of the species was found where the stream is deeper and flowing slower. Many $B$. cyri and $A$. petrubanarescui juveniles were observed in both Esendere and Onbaşılar drainages. Adult specimens of both species were found in Onbaşllar Stream. Probably, Esendere Stream mostly is preferring for spawning for both $B$. cyri and $A$. petrubanarescui. On the other hand, it was not found other species such as Capoeta capoeta and Oxynoemacheilus bergianus both of which are very widespread in the Lake Urmia drainages in Iran.

A. petrubanarescui, A. atropatenae and 0 . elsae were listed in Endemic fishes of Iran (Eagderi et al., 2018). This study provided an evidence the presence of these three species in Turkey. In this case, these species should be excluded from endemic fishes of Iran. None of these species have not been yet evaluated against IUCN criteria, therefore 
their current statues are "Not Evaluated". I strongly recommend that the conservation status of endemic fish species of Urmia Basin should be assessed against IUCN criteria. Because, day by day the problems growing and the lake is going to die. Fortunately, neither during the survey in this study nor by Ghasemi et al. (2015) any exotic species were found in Nazli-chay River and its drainages. However, as mentioned above, eleven exotic species inhabit the Lake basin. Some species among these, such as Carassius gibelio and Pseudorasbora parva, have a high invasiveness potential and threat on native species. Therefore, all endemic fishes of Lake Urmia seem in threat.

The type specimens of Alburnoides petrubanarescui collected by V.D. Vladykov in 1962 from Qasemlou Chay $\left(37^{\circ} 21^{\prime} \mathrm{N}, 45^{\circ} 09^{\prime} \mathrm{E}\right)$, Urmia basin (Bogutskaya and Coad, 2009). The species has not been found again after it was described by Bogutskaya and Coad (2009), despite its type locality and other drainages of the Lake Urmia have been searched several times. Even Iranian researchers speculate that may the species have never been there and it was described by the materials mislabelled (Jörg Freyhof, pers. comm., 2019). Recently, Jouladeh-Roudbar et al. (2020) have confirmed that the species cannot be found in the area even though extensive effort sampling the type locality and adjacent area by many researchers. Even, they emphasised the species possibly extinct and encouraged further surveys in the area. Fortunately, with the results of this study, the presence of the species in Lake Urmia basin has been confirmed. The threats on $A$. petrubanarescui populations

\section{REFERENCES}

Bogutskaya, N.G. \& Coad, B.W. (2009). A review of vertebral and fin-ray counts in the genus Alburnoides (Teleostei: Cyprinidae) with a description of six new species. Zoosystematica Rossica, 18, 126-173.

Eagderi, S., Jalili, P. \& Çiçek, E. (2018). Oxynoemacheilus elsae, a new species from the Urmia Lake basin of Iran (Teleostei: Nemacheilidae). FishTaxa, 3, 453-459.

Eagderi, S., Nikmehr, N., Çiçek, E., Esmaeili, H.R., Vatandoust, S. \& Mousavi-Sabet, H. (2019). Barbus urmianus a new species from Urmia Lake basin, Iran (Teleostei: Cyprinidae). International Journal of Aquatic Biology, 7, 239-244. DOI: 10.22034/ijab.v7i4.725

Eimanifar, A. \& Mohebbi, F. (2007). Urmia Lake (Northwest Iran): a brief review. Saline Systems, 3, 1-8. DOI: 10.1186/1746-1448-3-5

Ghasemi, H., Jouladeh-Roudbar, A., Eagderi, S., Abbasi, K., Vatandoust, S. \& Esmaeili H.R. (2015). Ichthyofauna of Urmia basin: Taxonomic diversity, distribution and conservation. Iranian Journal of Ichthyology, 2, 177-193.

IUCN (International Union for the Conservation of Nature) (2020). IUCN Red List of threatened species. Version 2014.3. Retrieved from http://www.iucnredlist.org (20 January 2020).

Jouladeh-Roudbar, A., Ghanavi, H.R. \& Doadrio, I. (2020). Ichthyofauna from Iranian freshwater: Annotated checklist, diagnosis, taxonomy, distribution and conservation assessment. Zoological Studies, 59, Od (in press).

Kaya, C., Turan, D. \& Ünlü, E. (2016). The latest status and distribution of fishes in upper Tigris River and two new records for Turkish freshwaters. seem greater. Populations of $A$. petrubanarescui may be restricted with Turkish part, and probably it is absent or very restricted in Iranian part.

Recently, a new barbel, Barbus urmianus, has been described in Mahabad-Chai River $\left(36^{\circ} 29^{\prime} 55.14 " \mathrm{~N}\right.$ $45^{\circ} 33^{\prime} 54.26 " \mathrm{E}$ ) a southern drainage of Lake Urmia (Eagderi et al., 2019). The Barbus specimens collected in Esendere and Onbaşılar streams in this study, morphologically identical with $B$. cyri. Therefore, these barbel population were acknowledged as $B$. cyri.

\section{ACKNOWLEDGEMENTS}

I would like to thank Cevdet Kaya and Safter Demir (Bitlis) for their help in the fieldwork, Esra Bayçelebi (Rize) for her help in laboratory and Hazel Baytaşoğlu (Rize) for producing the map. Many tanks to Jörg Freyhof (Berlin) and Davut Turan (Rize) for their remarkable comments to the earlier version of the manuscript. I also would like to thank to Ayşe Demirbaş and Utku Avcı (Rize) for improving the language of the manuscript, and Baran Yoğurtçuoğlu (Ankara) editing the pictures.

Fish collections were approved and granted by the Ministry of Food, Agriculture and Livestock, General Directorate of Fisheries and Aquaculture (codes for the protocols: 67852565-140.03.03-E.4052273 and 76000869804.01-00000919222). All applicable international, national or institutional guidelines for the care and use of animals were followed.

Turkish Journal of Fisheries and Aquatic Sciences, 16, 545-562. DOI: 10.4194/1303-2712-v16_3_07

Kaya, C., Bayçelebi, E. \& Turan, D. (2020). Taxonomic assessment and distribution of fishes in upper Kura and Aras river drainages. Zoosystematics and Evolution, 96(2), 325-344.

DOI: 10.3897 /zse.96.52241

Kelle, A. (1978). Dicle Nehri ve kollarında yaşayan balıklar üzerine taksonomik ve ekolojik araştırmalar. PhD, Diyarbakır Üniversitesi, Tıp Fakültesi Biyoloji Kürsüsü, Diyarbakır, Turkiye (in Turkish).

Kelts, K. \& Shahrabi, M. (1986). Holocene sedimentalogy of hypersaline Lake Urmia, northwestern Iran. Paleogeography, Paleoclimatology and Paleoecology, 54, 105-130. DOI: 10.1016/0031-0182(86)90120-3

Khaefi, R., Esmaeili, H.R., Geiger, M.F. \& Eagderi, S. (2017). Taxonomic review of the cryptic Barbus lacerta species group with description of a new species (Teleostei: Cyprinidae). FishTaxa, 2(2), 90-115.

Kuru, M. (1975). Dicle-Fırat, Kura-Aras, Van Gölü Karadeniz havzası tatlısularında yaşayan balıkların (Pisces) sistematik ve zoocoğrafik yönden incelenmesi. Doçentlik Tezi [Assoc. Prof. dissertation]. Atatürk Üniversitesi, Fen Fakültesi, Erzurum, Turkey (in Turkish).

Stevens, L.R., Djamali, M., Andrieu-Ponel, V. \& de Beaulieu, J.L. (2012). Hydroclimatic variations over the last two glacial/interglacial cycles at Urmia Lake, Iran. Journal of Paleolimnology, 47(4), 645-660. DOI: 10.1007/s10933-012-9588-3 